e-ISSN: 2721-3013, p-ISSN: 2721-3005

DOI: https://doi.org/10.38035/jafm.v1i3

Received: 28 April 2020, Revised: 10 May 2020, Publish: 2 July 2020

https://creativecommons.org/licenses/by/4.0/

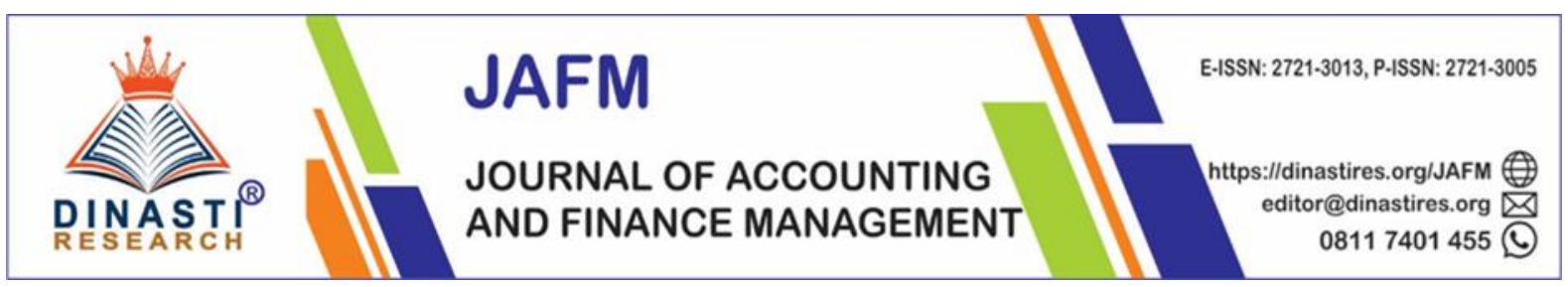

\title{
Do Character, Capacity, Capital, Collateral, and Conditions as Affect on Bad Loans
}

\author{
Ega Saputra ${ }^{1 *}$, Siti Resmi ${ }^{2}$, Hari Nurweni ${ }^{3}$, Tri Utomo Prasetyo ${ }^{4}$ \\ ${ }^{1)}$ Local Government Finance Office of Seluma Regency, Bengkulu Province, Indonesia \\ 2),3),4) Sekolah Tinggi Ilmu Manajemen YKPN Yogyakarta, Indonesia, sitiresmiamp@yahoo.com
}

Corresponding Author: Ega Saputra ${ }^{1}$

\begin{abstract}
Research on the analysis of the use of $5 \mathrm{C}$ (character, capacity, capital, collateral, and condition) in lending has been carried out. Analysis of lending is mostly seen from the perspective of lenders (banks or other lending institutions). In contrast to research in general, this study aims to analyze bad loan from the borrower perspective. This study examines and analyzes the effect of character, capacity, capital, collateral, and conditions (5C) on bad loans. This study uses primary data through questionnaires. The population is the borrower of funds in the Technical Service Unit at Local Government Finance Office, Sleman Regency, Yogyakarta Province, Indonesia. The sample was determined using purposive sampling and 105 respondents were obtained. Purposive sample criteria are fund borrowers who have difficulty in repaying loans and are included in the monitoring agenda. The results of the study prove that the character, capacity, and conditions affect on bad loans, while capital and collateral have no effect on bad loans
\end{abstract}

Keywords: Bad Loans, Character, Capacity, Condition, Capital, Collateral

\section{INTRODUCTION}

One of the ways undertaken by the government to improve the welfare of productive economic entrepreneurs is to provide loans in the form of capital strengthening funds. Capital strengthening funds are revolving funds provided to individuals, farmer groups, cooperatives and small to medium-sized enterprises (SMEs), management units of community empowerment program activities, and nonbank financial institutions that are intended as additional capital in developing their businesses. At the regency/city level, the mechanism for granting capital strengthening funds is regulated by the regent/mayor in regent/mayor regulations of each regency/city. Recipients of capital strengthening funds are required to return the funds according to the agreed repayment period, including contributing fees for the utilization of capital strengthening funds.

The existence of capital strengthening funds is expected to provide positive injections for community business groups that receive them. However, it is necessary to consider the constraints and problems in returning the capital strengthening fund. Indah (2019) found that 
capital strengthening funds in Sleman Regency were in arrears due to internal factors of $86.96 \%$ and due to business failures of $13.04 \%$. In the same regency, of the total amount of funds disbursed more than Rp166 million, the arrears reached $5.27 \%$ (https://republika.co.id/berita/mjzmvt/dana-bergulir-di-sleman-macet-527-persen,accessed February $\left.10^{\text {th }}, 2019\right)$.

According to Hasibuan (2006) bad loans are loans that are clarified of which the paymentsare not smoothly carried out by the customer concerned. This study analogizes bad loans in capital strengthening funds the same as bad loans in banking terms. To determine the feasibility of a customer in receiving capital strengthening funds, an analysis of the credit or credit feasibility is carried out. Creditworthiness analysis, which is generally used by banks, is known as 5C analysis (Sinkey, 1989). The 5C analysis consists of Character, Capacity, Capital (other sources of funds), Collateral, and Condition. The better the $5 \mathrm{C}$ rating the less likely there will be a bad loan. Conversely, the worse the assessment of $5 \mathrm{C}$, the more likely there will be bad loans. The existence of bad loans in capital strengthening funds shows that there is a mistake in determining who is worthy and not worthy to receive capital strengthening funds based on the five factors that serve as a reference for the eligibility of loans.

Research on bad loans analysis has been conducted in several studies with different results. The results of several previous studies explain that there is an influence of the customer's character on bad loans channeled by banks in Indonesia (Apriana, Wahyu, \& Irwansyah, 2017; Ernawati, 2014; Mukhsinati, 2011). Customer's capacity also has a role in the smooth payment of customer loan installments (Apriana et al., 2017; Mukhsinati, 2011; Noor, 2016). On the other hand, other sources of funds (capital) owned by customers apparently did not affect bad loans in Indonesia (Apriana et al., 2017; Ernawati, 2014; Noor, 2016). Assets that are used as collateral by customers also have an influence on bad loans (Apriana et al., 2017; Ernawati, 2014; Noor, 2016). The last aspect, the condition of the customer, apparently also has an influence on the smoothness of loan payments (Ernawati, 2014; Noor, 2016). The results of the study by Indah (2019) explained that the capital strengthening funds feasibility assessment conducted by the UPT PDPM BKAD of Sleman Regency was quite good but there were still shortcomings because in the loan assessment process, the creditors only used aspects of the character and condition of economy but did not use other aspects so that improvements need tobe made in the application some aspects of $6 \mathrm{C}$ to minimize the amount of arrears in loan.

The results of previous studies show that there is a gap. Research on the analysis of bad loans has also been done from the perspective of lenders. This study differs from previous studies, namely analyzing bad loans based on $5 \mathrm{C}$ from the perspective of the customers as the borrowers.

\section{LITERATURE REVIEW}

In this study, loans are defined as credit. The word credit comes from the word credere, which means trust. When a debtor obtains a loan, it means they gain trust. Meanwhile, for the lender, it means trusting someone that the funds will be repaid by their debtors. Loans disbursed may experience delays in installment payments. To prevent this, the lender can conduct an assessment of the feasibility of the loan submitted by prospective customers. At commercial banks, this assessment is carried out on prospective customers called 5C's, i.e. Character, Capacity, Capital, Collateral, and Condition (Koch \& MacDonald, 2015; Sinkey, 1989). Indicators of bad loans based on the provisions of the UPT PDPM BKAD of Sleman Regency are: (a) loans have not been repaid until maturity, and (b) in terms of legal and market conditions, collaterals cannot be disbursed at its fair value. 


\section{Character and Bad Loan}

Character refers to the customer's honesty and trustworthiness (Koch \& MacDonald, 2015). Character, in this study, is the nature or character of a person, in this case, a prospectivecustomer, to fulfill their obligations, namely repaying their debt. Bad loans are the customer's obligations that cannot be fulfilled. The better the character of the customer, the less likely theoccurrence of bad loans. The character of the customer can also be measured using indicators of bank and customer relations (Ferri, Murro, Peruzzi, \& Rotondi, 2019). On the other hand, Bharath \& Shumway (2008) uses the character of the business, not the customer, in predicting loan defaults. In Indonesia, Mukhsinati (2011) found a negative relationship between Characterand bad loans. This finding is supported by Noor (2016) and Ernawati (2014). Thus, Character has the opposite effect on bad loans. In other words, Character negatively affects bad loans.

H1: Character has a negative effect on bad loans at UPT PDPM BKAD of Sleman Regency.

\section{Capacity and Bad Loans}

Capacity is divided to two terms, in individual and in business term. An individual must be able to generate income and a business must have identifiable cash flow or alternative sources of cash to repay debt (Koch \& MacDonald, 2015). Capacity, in this study, is the ability of customers to manage their own business. If the customer's ability to manage their business is good, then the business will generate profits. The resulting profit is used to pay for the loans they have so that the loan is performing. So, the better the ability of customers to manage theirbusiness, the bad loans will decrease. This aspect can also be seen in customer business financial variables, such as leverage, equity volatility, profitability, cash-to-assets ratio, and business size (Caglio, Darst, \& Parolin, 2019). Mukhsinati (2011) found a negative relationshipbetween Capacity and bad loans. This is supported by Noor (2016) and Apriana et al. (2017). Thus, Capacity negatively affects bad loans.

$\mathrm{H} 2$ : Capacity has a negative effect on bad loans at UPT PDPM BKAD of Sleman Regency

\section{Capital and Bad Loans}

Capital is a source of financing owned by customers for businesses that will be financed by creditors. Capital can be measured by financial soundness and market standing (Koch \& MacDonald, 2015). This capital analysis is intended to see the customer's own capital that is embedded in his/her business and how much comes from other parties so that their responsibilities towards loans are proportional. The greater the customer's capital embedded inhis/her business, the better the assessment of capital. If one day the customer is unable to repaythe loan he/she has, his/her capital embedded in his business can be used as an asset to pay forthe loan so that there is no bad loan. So the more the amount of capital the customer has, the bad loans will decrease. Mukhsinati (2011) found a negative relationship between capital and bad loans. This shows that Capital negatively affects bad loans.

H3: Capital has a negative effect on bad loans at UPT PDPM BKAD of Sleman Regency.

\section{Collateral and Bad Loans}

Collateral is the lender's secondary source of repayment or security in the case of default (Koch \& MacDonald, 2015). In this study, collateral is an asset that is pledged by prospective customers, both physical and non-physical, as collateral for the borrowed funds. The collateralprovided must exceed the loan received. If at any time the customer is unable to repay his/her loan, the assets used as collateral will be used to repay his/her loan. The greater the collateral, the greater the tendency of customers to repay the loan in order to regain his/her pledged collateral. The assets that are pledged can be tangible or intangible. Tangible assets can actually increase bank risk. Margaritis \& Psillaki (2010) argue that tangible assets 
pledged by customersshow evidence of good guarantees and can be used to track and monitor customers. In addition, banks tend to ask for guarantees from customers when bank competition is low (Hainz, Weill,\& Godlewski, 2013). On the other hand, multi finance firms tend to lower collateral requirements (Hainz et al., 2013) and reduce the cost of funds to be competitive (Fungáčová, Shamshur, \& Weill, 2017). Moro, Lucas, \& Kodwani (2012) argue that collateral is not important, the most important thing is the bank's trust in customers. This is because guarantees are usually only done at the beginning of the loan application, then banks use their trust in accepting repeated loan applications. In Indonesia, Noor, (2016) found a negative relationshipbetween collateral and bad loans. This finding is supported by Apriana et al. (2017) and Ernawati (2014). Therefore, Collateral has an opposite effect on bad loans.

H4: Collateral has a negative effect on bad loans at UPT PDPM BKAD of Sleman Regency.

\section{Condition and Bad Loans}

Conditions refer to the economic environment or industry-specific supply, production, and distribution factors influencing a firm's operations (Koch \& MacDonald, 2015). Conditionin this study means the economic condition in customers' business, whether it will survive significant economic fluctuations in the future. If economic conditions in the future are good, then the survivability of the customers' business will also be good so that the customer is able to generate profits to pay off the loan. So, the better the conditions of the customer, the bad loans will decrease. Noor (2016) found that there is a negative relationship between Conditionand bad loans. This shows that Condition negatively affects bad loans.

H5: Condition has a negative effect on bad loans at UPT PDPM BKAD of Sleman Regency.

\section{RESEARCH METHODS}

This research is a quantitative research. The population of this study is customers who fall into the category of bad loans in the capital strengthening fund distribution program managed by UPT PDPM BKAD of Sleman Regency. The determination of the sample in this study uses a nonprobability sampling technique with a purposive sampling method. The criteriaused in the purposive sampling method are: (1) the customer experiences a bad loan, (2) the customer is on the monitoring agenda by UPT PDPM BKAD of Sleman Regency.

The number of samples in this study was determined by the number-of-questions method, which is 5 times the number of questions (Hair, Black, Babin, \& Anderson, 2009). The number of questions in this study were 21 items so that the number of samples needed was 105 samples. This study uses a questionnaire to retrieve data from respondents. This study uses a Likert scale with a rating score: a score of 1 shows strongly disagree, 2 shows disagree, 3 shows doubt, 4 shows agree, and 5 shows strongly agree. The questionnaire was given to 105 respondents randomly according to the study criteria. Of the 105 respondents, all of them were willing to fill out the questionnaire so that the determined number of samples had been fulfilled. The statistical technique for analyzing data is multiple linear regression processed with the help of SPSS 20 software.

\section{RESULTS AND DISCUSSION Validity and Reliability Test} Table 1.

The results of the validity and reliability based on the measurements can be seen in

Table 1. Test Results of Validity and Reliability

\begin{tabular}{lccc}
\hline Variables & Items & Pearson Corellation & Cronbach Alpha \\
\hline Character $(\mathrm{X} 1)$ & A1 & 0,749 & 0,489 \\
& A2 & 0,638 & \\
A3 & 0,724 & \\
\hline
\end{tabular}




\begin{tabular}{llll}
\hline Capacity(X2) & B1 & 0,678 & 0,619 \\
& B2 & 0,796 & \\
& B3 & 0,581 & \\
\hline B4 & 0,668 & 0,254 \\
& C1 & 0,542 & \\
& C2 & 0,641 & 0,651 \\
C3 & 0,487 & \\
Collateral(X4) & C4 & 0,549 & 0,201 \\
& D1 & 0,622 & \\
& D2 & 0,818 & 0,299 \\
Condition(X5) & D3 & 0,606 & \\
& D4 & 0,739 & \\
& E1 & 0,556 & \\
& E2 & 0,635 & \\
\hline Bad loans(Y) & E3 & 0,398 & \\
& E4 & 0,582 & \\
\hline
\end{tabular}

Based on Table 1, it can be explained that the Pearson Corellation value of each question item shows a greater number than the r-table value (0.1918). This shows that each question item is valid. Based on the Cronbach Alpha value, each variable has an alpha greater than r-table (0.1918). Thus, all measures of each variable are reliable.

\section{Multiple Linear Regression Analysis}

This study used multiple linear regression analysis in testing the research hypotheses. First, we tested the feasibility of the model using the overall significance test. Overall significance test can be performed using analysis of variance or ANOVA (Gujarati \& Porter,2009).

Table 2. F-Test Results

ANOVA $^{\mathbf{a}}$

\begin{tabular}{rlrrrrr}
\hline & Model & Sum of Squares & Df & Mean Square & F & Sig. \\
\hline \multirow{3}{*}{1} & Regression & 105,545 & 5 & 21,109 & 66,458 &, $000^{\mathrm{b}}$ \\
\cline { 2 - 5 } & Residual & 31,445 & 99 & \multicolumn{2}{c}{, 318} & \\
\cline { 2 - 5 } & Total & 136,990 & 104 & & \\
\hline
\end{tabular}

Source: Processed data.

ANOVA test ( $F$ test) in Table 2 obtained the calculated $F$ value of 66.458 with a probability of 0,000 . The probability value is less than 0.05 so that the regression model can be used to predictbad loans. In other words, it can also be said that Character, Capacity, Capital, Collateral, and Conditions together affect bad loans. The model also fulfills classical assumptions, namely (1) linear in parameters, (2) no perfect collinearity, (3) homoskedasticity, and (4) normally distributed residuals.

The next step of analysis is to test which independent variables partially affect bad loans. For this reason, a t-test was conducted (Wooldridge, 2016)

Table 3. t-Test Results

Coefficients $^{\mathrm{a}}$

\begin{tabular}{|c|c|c|c|c|c|}
\hline \multirow[t]{2}{*}{ Model } & \multicolumn{2}{|c|}{$\begin{array}{l}\text { Unstandardized } \\
\text { Coefficients }\end{array}$} & $\begin{array}{c}\text { Standardized } \\
\text { Coefficients }\end{array}$ & \multirow[t]{2}{*}{$\mathrm{t}$} & \multirow[t]{2}{*}{ Sig. } \\
\hline & $\mathrm{B}$ & Std. Error & Beta & & \\
\hline (Constant) & 12,976 & 625 & & 20,762 &, 000 \\
\hline Character &,- 203 & ,045 &,- 277 & $-4,500$ & ,000 \\
\hline 1 Capacity &,- 332 & ,035 &,- 623 & $-9,572$ & ,000 \\
\hline
\end{tabular}




\begin{tabular}{lccccc}
\hline Capital Collateral &, 043 &, 035 &, 072 & 1,250 &, 214 \\
\cline { 2 - 6 } \begin{tabular}{l} 
Condition \\
\cline { 2 - 6 }
\end{tabular} &,- 046 &, 028 &,- 094 & $-1,650$ &, 102 \\
\cline { 2 - 6 } &,- 083 &, 035 &,- 127 & $-2,358$ &, 020 \\
\hline
\end{tabular}

a. Dependent Variable: Pinjaman Macet

Source: Processed data

Table 3 shows the results of multiple linear regression. Based on Table 3, it appears that Character has a significant negative effect on bad loans. In addition, Capacity also shows a significant negative effect on bad loans. Conditions also has a statistically significant negativeeffect on bad loans. These can be seen from the unstandardized beta coefficients, each of which shows a negative sign in coefficient value of Character, Capacity, and Conditions. Their significances can be seen from the probability value of each variable that shows a value less than the error tolerance limit, which is $\alpha=0.05$. Thus, the research hypotheses, namely $\mathrm{H} 1, \mathrm{H} 2$, and $\mathrm{H} 5$, can be accepted.

The variable Capital shows a positive unstandardized beta coefficient with a probability value of 0.214 (greater than 0.05). This shows that Capital has no influence on bad loans. Thus, the third research hypothesis $(\mathrm{H} 3)$ is rejected.

On the other hand, the Collateral variable has a negative unstandardized beta coefficient. This is consistent with a prior hypothesis in this study. However, apparently Collateral is statistically insignificant in influencing bad loans. This can be seen from the probability value $(0.102)$ which is greater than $\alpha=0.05$.

The final step of data analysis in this study is to measure how far the ability of the model to influence the variation of the dependent variable by looking at the coefficient of determination. The coefficient of determination is indicated by the adjusted $\mathrm{R} 2$ value because this study uses more than one independent variable (Gujarati \& Porter, 2009).

Table 5. Test Results of the Coefficient of Determination $\left(\mathbf{R}^{2}\right)$ Model Summary

\begin{tabular}{ccccc}
\hline Model & $\mathrm{R}$ & $\mathrm{R}$ Square & Adjusted R Square & $\begin{array}{c}\text { Std. Error of the } \\
\text { Estimate }\end{array}$ \\
\hline 1 &, $878^{\mathrm{a}}$ &, 770 &, 759 &, 56359 \\
\hline
\end{tabular}

a. Predictors: (Constant), Condition, Capacity, Collateral, Capital, Character

The result of Adjusted $\mathrm{R}^{2}$ in Table 5 shows that as much as $75.9 \%$ of the variation in bad loans can be explained by variations in Character, Capacity, Capital, Collateral, and Condition; while the rest, as much as $24.1 \%$, variations in bad loans are explained by variations of other variables that are not included in the model. Four of the five variables are in line with a priori hypotheses, where three of them are statistically significant at 5\%, namely Character, Capacity, and Condition. The result shows that Collateral is in line with a priori hypothesis, butstatistically not significant at $5 \%$. On the other hand, the relationship between Capital and badloans found to be positive, which is not in line with a priori hypothesis, and statistically insignificant at 5\%. Furthermore, Capacity is the most important aspect of preventing the occurrence of bad loans. This can be seen from the absolute value of the standardized beta of Capacity that shows the highest number among others, which is 0.623 .

\section{Discussion}

Testing for Character, the result shows that the customers' character has a negative effecton bad loans at UPT PDPM of Sleman Regency. The worse the customers' character, the higher the bad loans. This relates to poor customer behavior, such as dishonesty, broken promises, excessive lifestyle, and loans that are not used properly (for example, loans are not used for business but are used for personal purposes), resulting in bad loan payments. This research supports findings by Apriana et al. (2017); Ernawati (2014); and Mukhsinati 
(2011). The creditanalyst of UPT PDPM of Sleman Regency must pay more attention to the aspects of customers' character, especially the nature of honesty, sincerity, intelligence, health, habits, temperamental, excessive pride, and so on. Thus, CSF Programs of Sleman Regency can prevent the occurrence of bad loans.

Testing for Capacity, the result shows that customers' capacity has a negative effect on bad loans at UPT PDPM of Sleman Regency. The worse the customers' capacity, the higher the bad loans. Capacity depicts customers' ability to fulfill their obligations. The ability to pay is assessed from business activities and their ability to manage the business. The results showed that customers who experience bad loans are caused by the inability of customers to manage their businesses so that the income received is relatively declining and results in loan payments becoming bad. This study supports the research findings conducted by Apriana et al. (2017); Mukhsinati (2011); and Noor (2016).

Testing for Capital, the result shows that customers' capital has no effect on bad loans at UPT PDPM of Sleman Regency. Capital can be assessed from the customers' wealth or financial condition. This study supports research conducted by Apriana et al. (2017); Ernawati (2014); and Noor (2016). In terms of CSF programs provided by the Sleman Government, customers' capacity is the least requirement in considering the customers' loan application. This means that if there is still doubt about the other four aspects, namely character, capacity, collateral, and condition, then they can assess the customers' wealth through basic checking, i.e. BI Checking.

Testing for Collateral, the result shows that the customers' collateral has a negative effecton bad loans at UPT PDPM of Sleman Regency although it is statistically insignificant. Collateral is a guarantee that can gain the level of lender's trust that the customers will repay the loan. Customers who have loans at UPT PDPM of Sleman Regency have pledged assets ascollateral as a safety tool from uncertainty in the future when the loan must be repaid. This means that the collateral can be confiscated if it turns out that the customers really cannot fulfill their obligations. This finding is in line with the findings of Apriana et al. (2017); Ernawati, (2014); and Noor, (2016).

Testing for Condition, the result indicates that customers' condition negatively affects bad loans at UPT PDPM of Sleman Regency. The worse the conditions of the customers, the higher the bad loans. The variable Condition shows a condition that arises as a result of an unfavorable event that makes the loss of the customers' ability to pay their obligations. For example interest rates, calamities, inflation, and natural disasters. This finding supports previous studies conducted by Ernawati (2014) and Noor (2016).

\section{CONCLUSIONS}

This study examines the factors that determine the high non-performing loans in UPT PDPM BKAD Sleman Regency in 2016. Unlike previous studies, this study analyzes the factors that influence bad loans from the side of the borrower of funds (debtor) who experience bad loans.

The results of the data analysis found that the $5 \mathrm{C}$ assessment jointly affected the bad loans at UPT PDPM BKAD Sleman Regency. Character negatively affects bad loans. In addition, capacity also has a negative effect on bad loans. On the other hand, Capital and Collateral haveno effect on bad loans. The last variable, Conditions, has a negative effect on bad loans.

In the case of the Capital Strengthening Fund program provided by the Sleman Government, customer capacity is the final requirement in considering customer loan applications. This means that if there are still doubts about the other four aspects, namely character, capacity, guarantee, and condition, then they can assess the customer's wealth through basic checking, namely BI Checking. 


\section{REFERENCES}

Apriana, S., Wahyu, D., \& Irwansyah. (2017). Analisis Pengaruh Prasyarat Kredit (5C) terhadap Kelancaran Pembayaran Angsuran Nasabah di Bank Kalsel Unit Sentra AntasariBanjarmasin. Jurnal Bisnis Dan Pembangunan, 6(1), 10-18.

Bharath, S. T., \& Shumway, T. (2008). Forecasting default with the Merton distance to default model. Review of Financial Studies, 21(3), 1339-1369. https://doi.org/10.1093/rfs/hhn044

Caglio, C., Darst, R. M., \& Parolin, E. (2019). Half-full or half-empty? Financial institutions, CDS use, and corporate credit risk. Journal of Financial Intermediation, 40(March). https://doi.org/10.1016/j.jfi.2019.03.001

Ernawati. (2014). Analisa Pengaruh Penilaian Prinsip 5C terhadap Non Performing Loan pada PT Bank Rakyat Indonesia (Persero) Tbk KCP Baranangsiang Bogor. Institut Pertanian Bogor.

Ferri, G., Murro, P., Peruzzi, V., \& Rotondi, Z. (2019). Bank lending technologies and credit availability in Europe: What can we learn from the crisis? Journal of International Moneyand Finance, 95, 128-148. https://doi.org/10.1016/j.jimonfin.2019.04.003

Fungáčová, Z., Shamshur, A., \& Weill, L. (2017). Does bank competition reduce cost of credit? Cross-country evidence from Europe. Journal of Banking and Finance, 83, 104-120.https://doi.org/10.1016/j.jbankfin.2017.06.014

Gujarati, D. N., \& Porter, D. C. (2009). Basic Econometrics (5th ed.). New York: McGrawHiII.

Hainz, C., Weill, L., \& Godlewski, C. J. (2013). Bank Competition and Collateral: Theory and Evidence. Journal of Financial Services Research, 44(2), 131-148. https://doi.org/10.1007/s10693-012-0141-3

Hair, J. F. J., Black, W. C., Babin, B. J., \& Anderson, R. E. (2009). Multivariate Data Analysis (7th ed.). https://doi.org/10.1016/j.foodchem.2017.03.133

Hasibuan, M. S. (2006). Dasar-dasar Perbankan. Jakarta: Bumi Aksara.

Indah, W. K. (2019). Analisis Kredit pada UPT Pengelolaan Dana Penguatan Modal (PDPM)BKAD Kabupaten Sleman. Universitas Gadjah Mada.

Koch, T. W., \& MacDonald, S. S. (2015). Bank Management (8th ed.). https://doi.org/10.1108/eb002056

Margaritis, D., \& Psillaki, M. (2010). Capital structure, equity ownership and firm performance.Journal of Banking and Finance, 34(3), 621-632. https://doi.org/10.1016/j.jbankfin.2009.08.023

Moro, A., Lucas, M. R., \& Kodwani, D. (2012). Trust and the Demand for Personal Collateral in SME - Bank Relationships. Trust and the Demand for Personal Collateral in SME - Bank Relationships, 16(1), 57-79.

Mukhsinati, S. (2011). Analisis Faktor-faktor Penyebab Terjadinya Kredit Macet pada Bank " $X$ ” di Kabupaten Jember (Universitas Jember). https://doi.org/10.16194/j.cnki.31$1059 / \mathrm{g} 4.2011 .07 .016$

Noor, P. N. H. (2016). Analisis Faktor-faktor yang Mempengaruhi Kredit Macet pada BankPengkreditan Rakyat Artha Pamenang Warujayeng. Universitas Nusantara PGRI Kediri.

Sinkey, J. F. (1989). Commercial Bank Financial Management in the Financial Industry (3rd ed.). New York: MacMilan.

Wiyono, G. (2011). Merancang Penelitian Bisnis dengan Alat Analisis SPSS 17.0 \& SmartPLS 2.0. Yogyakarta: UPP STIM YKPN.

Wooldridge, J. M. (2016). Introductory Econometrics (6th ed.). Boston: Cengage Learning. 